\title{
LIPOPROTEINS IN CORONARY ARTERY DISEASE
}

\author{
BY \\ E. M. M. BESTERMAN \\ From the Institute of Cardiology \\ Received February 14, 1957
}

Lesions of the arterial intima were described in 1804 by Scarpa and cholesterol deposits in the arteries were recognized by Vogel in 1847. The descriptive term atherosclerosis was introduced by Marchand (1904). Subsequently Anitschkow (1913) demonstrated a relationship between these lesions and the serum lipids by the experimental production of atheroma in rabbits fed on cholesterol. The quantitative and qualitative abnormalities of the serum lipoproteins associated with atheroma are not completely understood. The lipoproteins are complex mixtures of lipids linked to the plasma proteins, which have been investigated by three techniques: Cohn fractionation (1950), ultracentrifugal separation (Gofman, 1950; Lewis and Page, 1949), and electrophoresis by both the Tiselius and filter methods. Paper electrophoresis, which is the crudest of these methods but relatively simple and requiring no expensive apparatus, has been used by Nikkila (1953), Swahn (1953), Dangerfield (1955) and others to investigate lipoproteins in diseases with gross lipid abnormalities such as biliary cirrhosis, diabetes, nephrosis, and xanthomata.

The lipoproteins fall into two main groups, $\beta$ and $\alpha$, so called by virtue of their proximity to the $\beta$ and $\alpha 1$ globulins on electrophoresis. Of the total serum cholesterol, 64 per cent is contained in the $\beta$ and 24 per cent in the $\alpha$ lipoproteins. Relatively more phospholipid is present in the $\alpha$ lipoprotein; thus the $\alpha \mathrm{C} / \mathrm{P}$ ratio is lower $(0.63)$ than is the $\beta \mathrm{C} / \mathrm{P}$ ratio (1.24) (Nikkila, 1953).

In atheroma, the lipid distribution is altered: an increase of $\beta$, and a reduction of the $\alpha$ lipoprotein has been described by Barr (1951), Raynaud (1953), and Nikkila (1953). Oliver and Boyd (1955) have demonstrated corresponding alterations in the absolute cholesterol content of the two lipoproteins. The increased serum $\mathrm{C} / \mathrm{P}$ ratio in atherosclerosis is another reflection of this redistribution. However, these changes are not sufficiently specific for diagnostic purposes in the individual patient. Page (1954) has correlated the lipoproteins separated by electrophoresis with those found on ultracentrifugation, the Sf 10-20 group which is increased in atheroma (Gofman, 1950) corresponding to the $\beta$ lipoprotein.

Using paper electrophoresis, Dangerfield noted a pre- $\beta$ lipoprotein, not commented on previously, in various conditions associated with grossly abnormal lipids, as well as in some cases of coronary artery disease. It seemed possible that this fraction might provide a more specific indication of lipid abnormality in atheroma. It was therefore decided to use Dangerfield's technique in an attempt to evaluate the relationship of this pre- $\beta$ lipoprotein to atheroma and to coronary artery disease in particular.

Technique. Electrophoresis was carried out by the "draped" or hanging technique of Flynn and de Mayo (1951), using $35 \times 5 \mathrm{~cm}$. strips of Whatman No. 3 paper: a thick paper is necessary to accommodate the amount of serum necessary $(0.16 \mathrm{ml}$.) for satisfactory lipoprotein analysis. After application of serum these strips were saturated with barbitone buffer, $p \mathrm{H} 8 \cdot 6$, and a current of $1 \mathrm{~mA}$ per strip at $250 \mathrm{~V}$. was applied for 17 hours. For shorter runs of 7 hours, $3 \mathrm{~mA}$ per strip was necessary. After drying, the papers were bisected longitudinally; one half was then stained for proteins with Light Green and the other half stained for lipoproteins with Sudan Black B 
using Swahn's (1953) technique. The Latner photodensitometer (Latner et al., 1954) was then used to plot graphs from the paper electrophoretograms.

Material and Method. In a study of patients with atheroma it is impossible to provide for comparison a group of normal subjects who are indisputably free from atheroma, and so our control patients undoubtedly include many with some degree of atheroma. In view of such a possible weighting of the control group, any difference emerging on comparison between these and the abnormal subjects may be of greater significance than appears. The 124 control subjects were selected from patients with no clinical, radiological, or electrocardiographic evidence of ischæmic heart disease or atheroma: most were suffering from rheumatic or congenital heart disease and the remainder had no evidence of any heart disease.

The second group of subjects was composed of 200 patients with unequivocal clinical and electrocardiographic evidence of ischæmic heart disease. A third smaller group of 42 patients with aortic atheroma was also studied: they had aortic calcification on fluoroscopy, but no evidence of ischæmic heart disease. The lipoproteins of these subjects were investigated to determine the difference, if any, between gross aortic atheroma and predominant coronary atheroma. For more accurate comparison of the findings between each of these three main groups of patients, further subdivisions were made according to sex and 20-year age groups.

Investigation. Preliminary studies showed that the use of fasting sera had no advantages as the lipoprotein pattern was identical in sera taken before and after a meal. Plasma and serum lipoproteins were identical. Storage of serum at $-4^{\circ} \mathrm{C}$. for up to three weeks caused no deterioration. Many of the ischæmic patients were in hospital for treatment of acute cardiac infarction, and the transient changes in the lipoprotein pattern observed in these cases will be reported separately. For this reason only those serum samples collected two or more weeks after infarction were used in this study.

Using the Latner densitometer, graphs were derived from the electrophoretograms (Fig. 1 and 2 ) and the areas of the $\beta$, pre- $\beta$, and $\alpha$ lipoproteins were determined by planimetry. On these

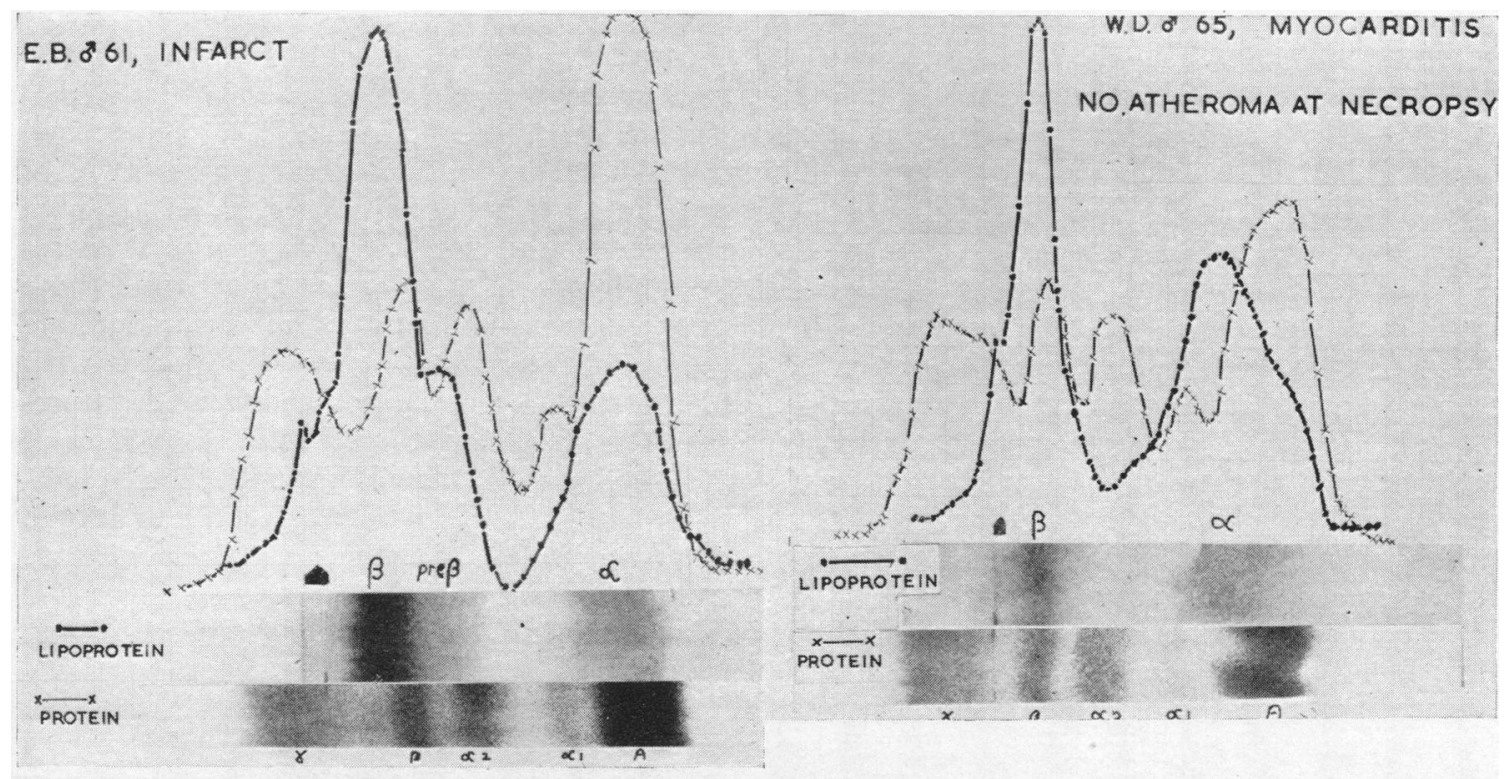

Fig. 1.-Typical electrophoretograms and graphs of plasma proteins and lipoproteins from the serum of a patient with ischæmic heart disease.

FiG. 2.-Electrophoretograms and graphs of plasma proteins and lipoproteins from the serum of a control subject. 
graphs the curve of the pre- $\beta$ lipid was partially superimposed on that of the $\beta$ lipoprotein. To obtain the area of each of the lipid bands a perpendicular line was drawn from the nadir of the intersection of the two curves to the boundary between the lipoproteins on the electrophoretogram in position beneath the graph. The resultant pre- $\beta$ and $\beta$ areas will be nearly equal to the true area of each curve when extrapolated (Fig. 3). Variations in staining made it impossible to compare

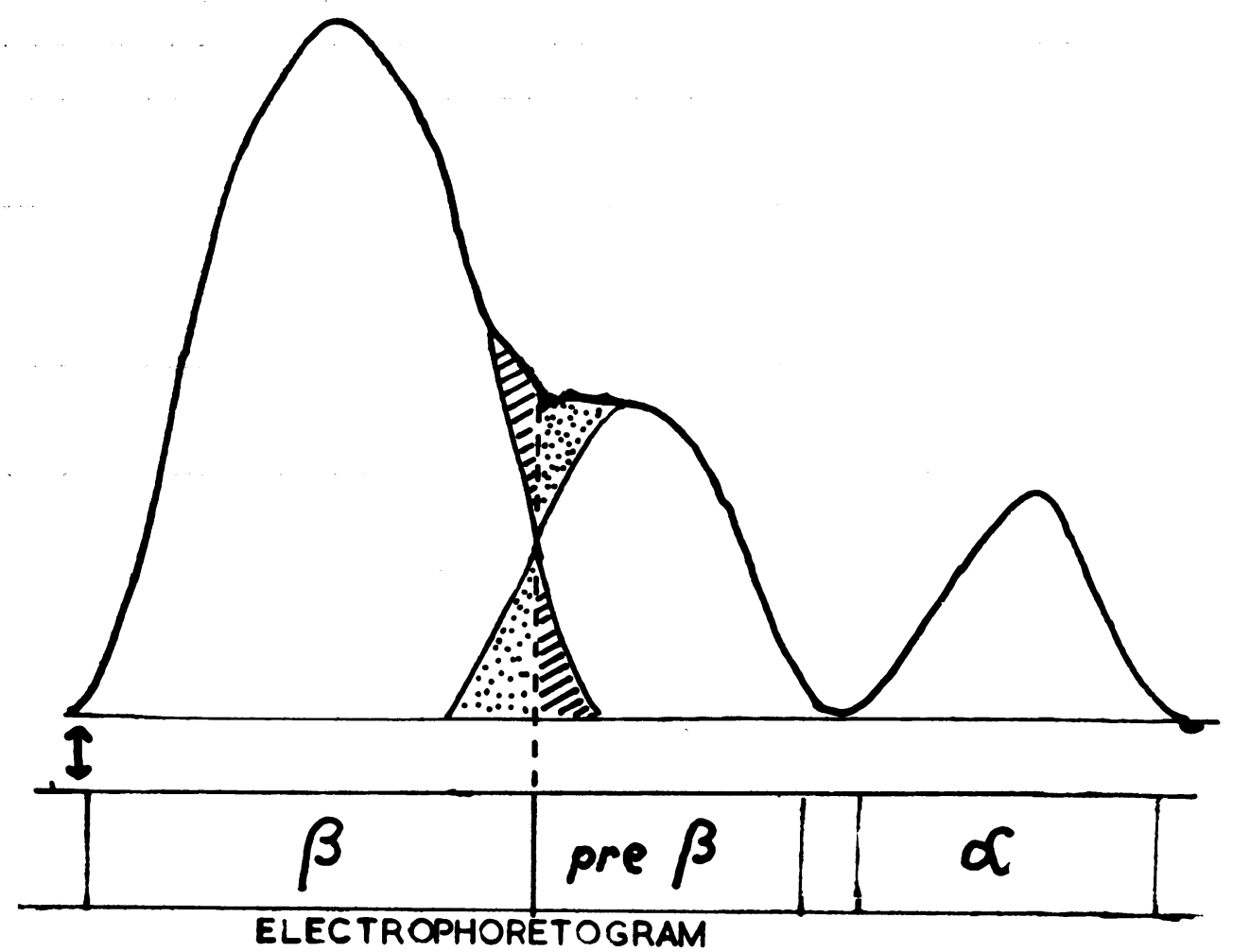

Fig. 3.-Diagram to illustrate the method of determining the areas of the pre- $\beta$ and $\beta$ curves when projected as a graph from the electrophoretogram.

the individual lipoproteins in any series of electrophoretograms. Therefore the area of each lipoprotein was expressed as a fraction of the total area of lipoproteins in each electrophoretogram. The differences between the mean findings in the control, and those in the ischæmic and atheromatous groups were then subjected to statistical analysis, and the probability was assessed of obtaining the observed differences by chance alone.

Results. The findings are summarized in Table I and the histograms in Fig. 4 and 5 were derived from this table. There were 46 control subjects under the age of 30 but there were no patients with ischæmic heart disease or atheroma in this age group. The $\alpha$ and $\beta$ fractions were approximately equal, whereas in the older controls an increasing disparity became apparent. A pre- $\beta$ lipoprotein was present in some of these younger control subjects.

There was no obvious difference in the $\beta$ fraction between the three main groups, in either sex, at any age. Individual variations occurred, but the only significant increase of this lipoprotein was seen in a few patients suffering from xanthomatosis and hypercholesterolæmia who were not included in the present study.

A highly significant increase in pre- $\beta$ lipoprotein distribution was found in both the ischæmic 
TABLE I

Mean Values of each Lipoprotein Fraction in Control Groups compared with those in the ISCHEMIC AND ATHEROMATOUS GROUPS

\begin{tabular}{|c|c|c|c|c|c|c|}
\hline \multirow{4}{*}{ 点 } & Age & & $\frac{\beta}{\beta+\text { pre }-\beta+\alpha}$ & $\frac{\text { pre }-\beta}{\beta+\text { pre }-\beta+\alpha}$ & $\frac{\alpha}{\beta+\text { pre- } \beta+\alpha}$ & $\begin{array}{l}\text { Number of } \\
\text { patents }\end{array}$ \\
\hline & $10-29$ & Control & $0.458 \pm 0.012$ & $0.069 \pm 0.013$ & $0.463 \pm 0.036$ & 27 \\
\hline & $30-49$ & $\begin{array}{l}\text { Control } \\
\text { Ischæmic } \\
\text { Atheroma }\end{array}$ & $\begin{array}{l}0.517 \pm 0.056 \\
0.499 \pm 0.021 \\
0.513 \pm 0.022\end{array}$ & $\begin{array}{l}0.083 \pm 0.016 \\
0.219 \pm 0.006 p<0.001 \\
0.192 \pm 0.010 p<0.001\end{array}$ & $\begin{array}{l}0.377 \pm 0.028 \\
0.279 \pm 0.010 p<0.001 \\
0.300 \pm 0.036 p<0.1\end{array}$ & $\begin{array}{r}18 \\
46 \\
9\end{array}$ \\
\hline & $50-69$ & $\begin{array}{l}\text { Control } \\
\text { Ischæmic } \\
\text { Atheroma }\end{array}$ & $\begin{array}{l}0.511 \pm 0.021 \\
0.491 \pm 0.013 \\
0.472 \pm 0.030\end{array}$ & $\begin{array}{l}0.093 \pm 0.014 \\
0.218 \pm 0.005 p<0.001 \\
0.180 \pm 0.015 p<0.001\end{array}$ & $\begin{array}{l}0.396 \pm 0.027 \\
0.277 \pm 0.007 p<0.001 \\
0.313 \pm 0.021 p<0.05\end{array}$ & $\begin{array}{r}16 \\
113 \\
19\end{array}$ \\
\hline \multirow{3}{*}{ 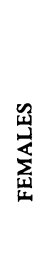 } & $10-29$ & Control & $0.475 \pm 0.025$ & $0.068 \pm 0.014$ & $0.455 \pm 0.029$ & 19 \\
\hline & $30-49$ & $\begin{array}{l}\text { Control } \\
\text { Ischæmic } \\
\text { Atheroma }\end{array}$ & $\begin{array}{l}0.512 \pm 0.016 \\
0.480 \pm 0.020 \\
0.466 \pm 0.022\end{array}$ & $\begin{array}{l}0.073 \pm 0.012 \\
0.205 \pm 0.012 p<0.001 \\
0.143 \pm 0.0004 p<0.001\end{array}$ & $\begin{array}{l}0.416 \pm 0.019 \\
0.315 \pm 0.028 p<0.01 \\
0.389 \pm 0.019 p<0.4\end{array}$ & $\begin{array}{r}30 \\
11 \\
2\end{array}$ \\
\hline & $50-69$ & $\begin{array}{l}\text { Control } \\
\text { Ischæmic } \\
\text { Atheroma }\end{array}$ & $\begin{array}{l}0.548 \pm 0.023 \\
0.491 \pm 0.025 \\
0.507 \pm 0.032\end{array}$ & $\begin{array}{l}0.116 \pm 0.015 \\
0.201 \pm 0.011 p<0.001 \\
0.159 \pm 0.024 p<0.2\end{array}$ & $\begin{array}{l}0.337 \pm 0.019 \\
0.282 \pm 0.022 p<0.1 \\
0.333 \pm 0.033 p<0.9\end{array}$ & $\begin{array}{l}14 \\
30 \\
12\end{array}$ \\
\hline
\end{tabular}

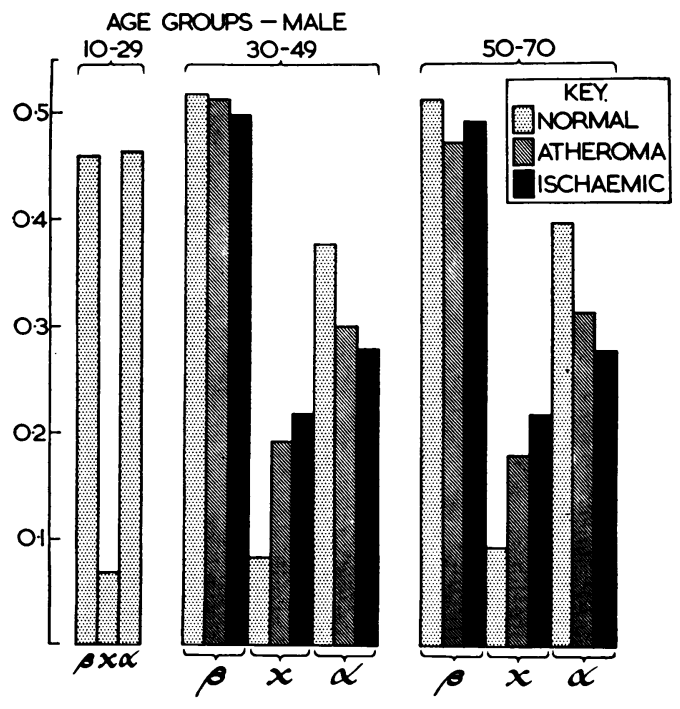

FIG. 4.-Histogram of the lipoprotein fractions in men. $x=$ pre $\beta$ lipoprotein. The scale indicates the fraction of the individual lipoprotein as a proportion of the total lipoproteins.
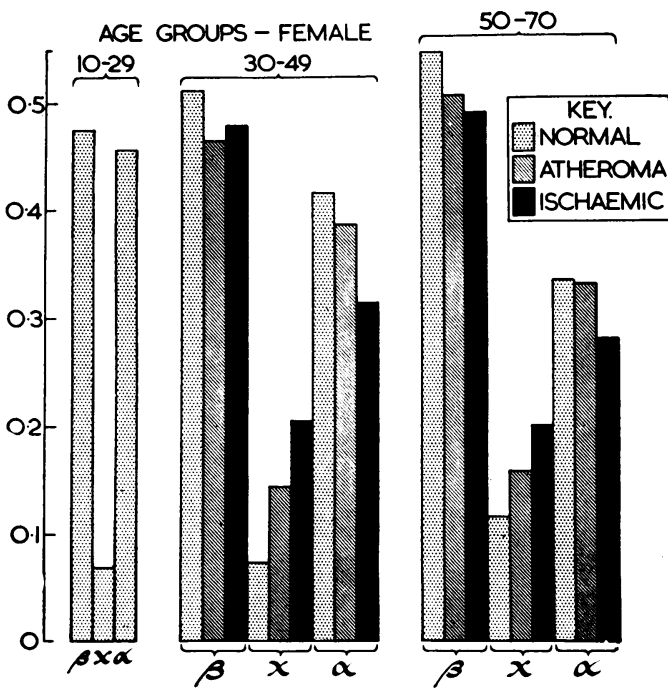

FIG. 5.-Histogram of the lipoprotein fraction in women. $x=$ pre $\beta$ lipoprotein. Scale as in Fig. 4. 
and atheromatous groups, especially in the former and particularly in men. The pre- $\beta$ lipid was found in some of the control subjects, and tended to increase slightly with age; it was most noticeable in women over 50 .

A pronounced diminution of the $\alpha$ lipoprotein was found in men with ischæmic heart disease, and also to some extent in men with atheroma. The $\alpha$ lipoproteins were diminished slightly in women with ischæmic heart disease, but not at all in women with uncomplicated atheroma. In the control group, women aged 30-49 appeared to have $\alpha$ lipoprotein fractions greater than men; whereas in older subjects this difference between the sexes was reversed.

The lipoprotein pattern in the electrophoretogram of Fig. 1 was typical of that obtained in the ischæmic subjects. A well defined pre- $\beta$ band was present and the $\alpha$ lipoprotein was diminished. By comparison the normal lipid distribution shown in Fig. 2 contained a large $\alpha$ lipoprotein fraction and no pre- $\beta$ band. This electrophoretogram was obtained from the serum of a patient who died subsequently from heart failure caused by a cardiopathy of unknown ætiology: no significant coronary atheroma was found at necropsy.

Pre $-\beta$ Lipoprotein. The pre- $\beta$ lipoprotein was found repeatedly in the sera of 198 out of the 200 ischæmic subjects (Fig. 6); but was consistently absent in two, in whom further interrogation

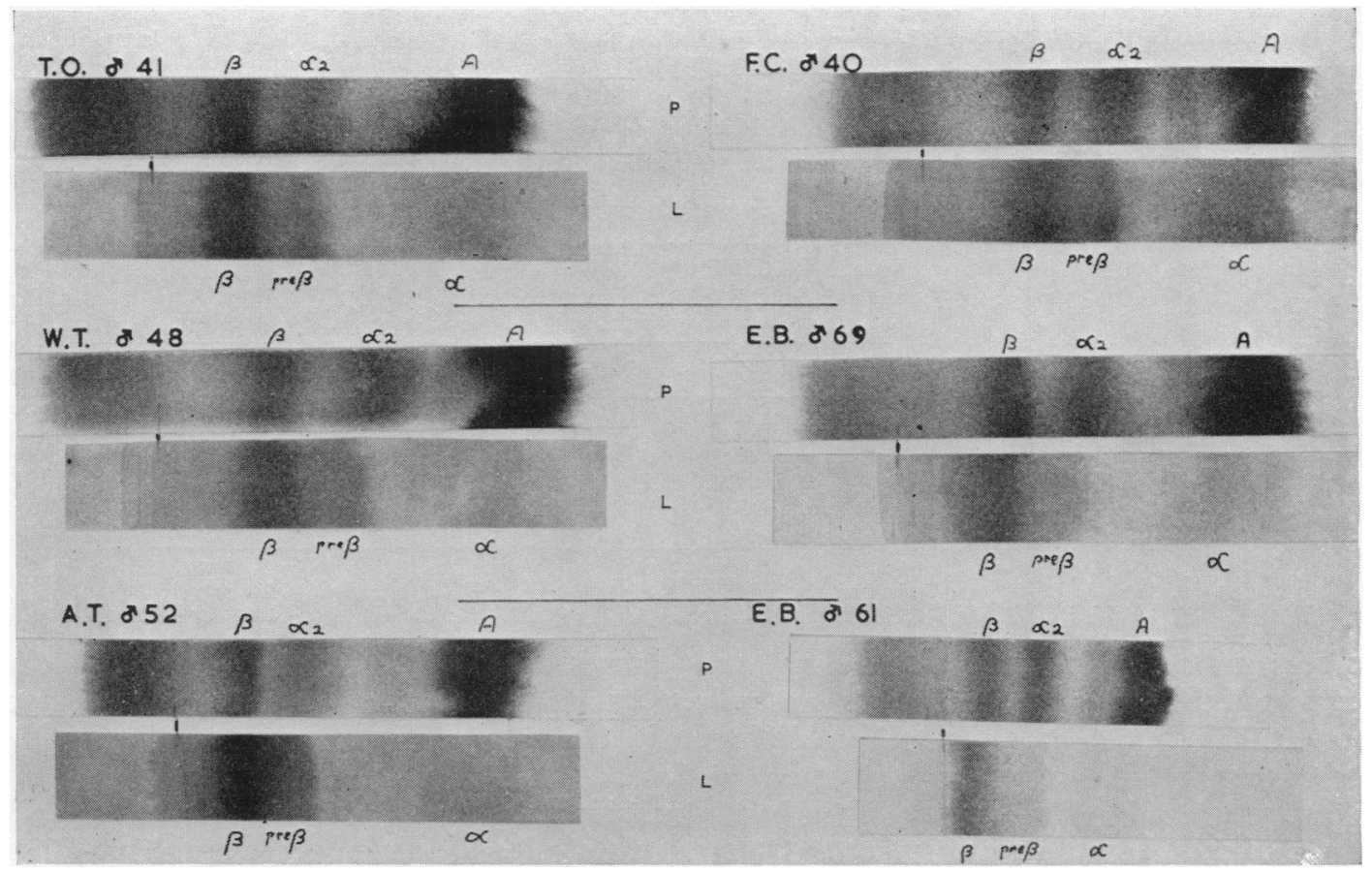

FIG. 6.-Paired electrophoretograms of plasma proteins (P) and lipoproteins (L) to illustrate the pre- $\beta$ band from six patients with ischæmic heart disease.

and investigation has revealed no explanation for the discrepancy. A pre- $\beta$ band was found on electrophoresis of the sera of some men and women, aged 20-30, and of some boys under 20 years old, but in no girls. In many of the control sera, the band was either indistinct or absent (Fig. 7).

In order to determine whether the pre- $\beta$ lipid was distinct in composition from the adjacent $\beta$ lipoprotein, extracts from each lipoprotein band were analysed by Dr. H. G. Sammons in Professor Frazer's department at Birmingham. The results are shown in Table II: the most obvious 


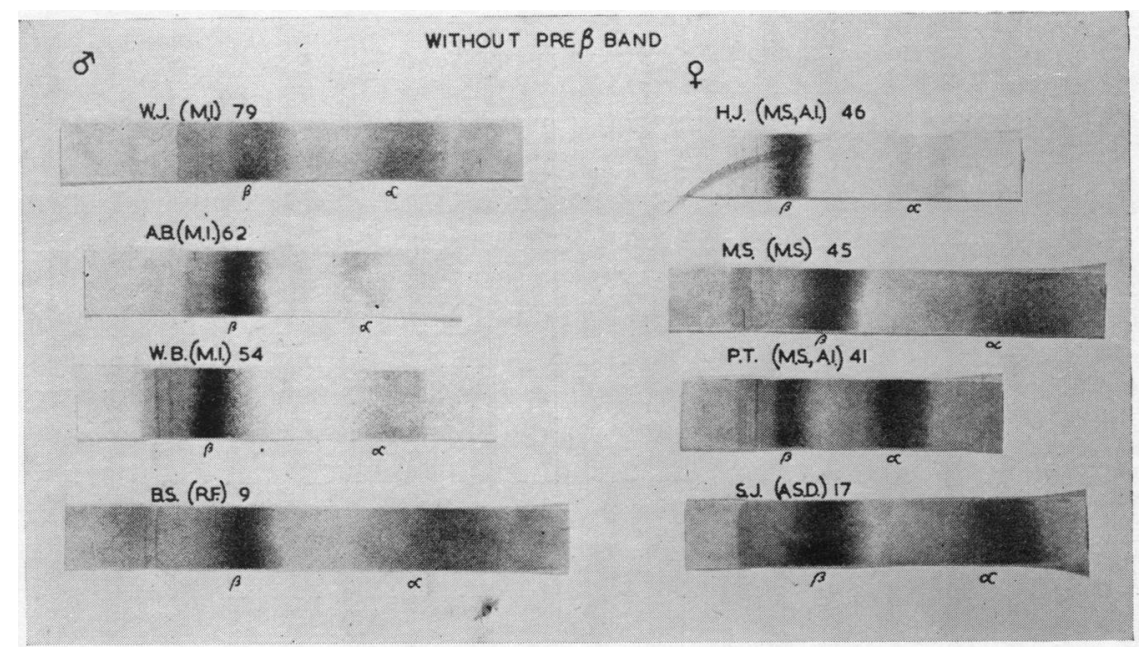

FIG. 7.-Electrophoretograms of the lipoproteins from 8 control subjects. No pre- $\beta$ lipoprotein present.

TABLE II

ANAlysis of Extractions of Individual Lipoproteins and the Neutral Fat Band

\begin{tabular}{c|c|c|c|c}
\hline & Total lipid & Cholesterol & $p$ & $\begin{array}{c}\text { Free fatty } \\
\text { acid }\end{array}$ \\
\cline { 2 - 4 } & mg. & $\%$ & $\%$ & $\%$ \\
\hline Neutral fat & 5.95 & 25 & 0.065 & 19 \\
$\beta$ & 12.30 & 55 & 0.037 & 14 \\
pre- $\beta$ & 7.40 & 34 & 0.040 & 11 \\
$\alpha$ & 7.05 & 20 & $0 \cdot 128$ & 16 \\
\hline
\end{tabular}

difference being that the pre- $\beta$ cholesterol content was 34 per cent whereas that of the beta lipid was 55 per cent. The composition of the pre- $\beta$ lipoprotein also appeared to be quite distinct from that of the neutral fat band at the point of application of the serum. Dangerfield has already reported that ethanol extraction of the lipoproteins after electrophoresis resulted in extraction of the $\beta$, leaving unchanged the pre- $\beta$ and $\alpha$ fractions.

This pre- $\beta$ band was found consistently in repeated studies of the same serum, and in serial samples of sera from the same subject. On comparison with the serum proteins the pre- $\beta$ lipoprotein is not constantly related either to the $\alpha 2$ or to the $\beta$ globulin, and appears to lie between the two (Fig. 6). It cannot therefore be termed an $\alpha 2$ lipoprotein, nor does it result from separation of the $\beta$ globulin into $\beta 1$ and 2 components. This separation of $\beta$ globulin has not been observed in any routine protein electrophoretograms, nor has it been achieved by alteration of the buffer as suggested by Laurall (1955); nor by use of a borate-barbitone at $p \mathrm{H} \mathrm{8.6.} \mathrm{The} \mathrm{pre-} \beta$ band is also demonstrable on electrophoresis in a horizontal tank, and does not appear to be an artefact due to the "draped" technique. This lipid was equally well seen on both short and long " runs," and does not vary with the degree of migration (Fig. 8). The lack of previous reports on this lipoprotein remain to be explained. Sudan 4 staining showed it as well as Sudan black B. However, the use of $0.06 \mathrm{ml}$. of serum instead of 0.12 resulted in a poorly defined band (Fig. 9). 


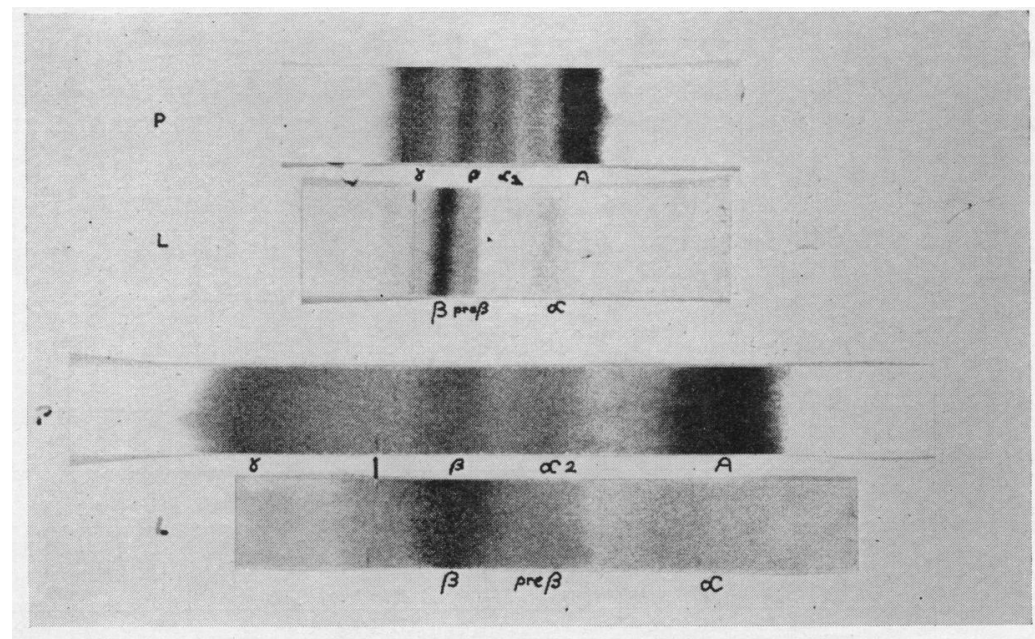

FIG. 8.-Paired electrophoretograms of plasma proteins (P) and lipoproteins (L) to demonstrate distinct pre $-\beta$ band irrespective of degree of migration.

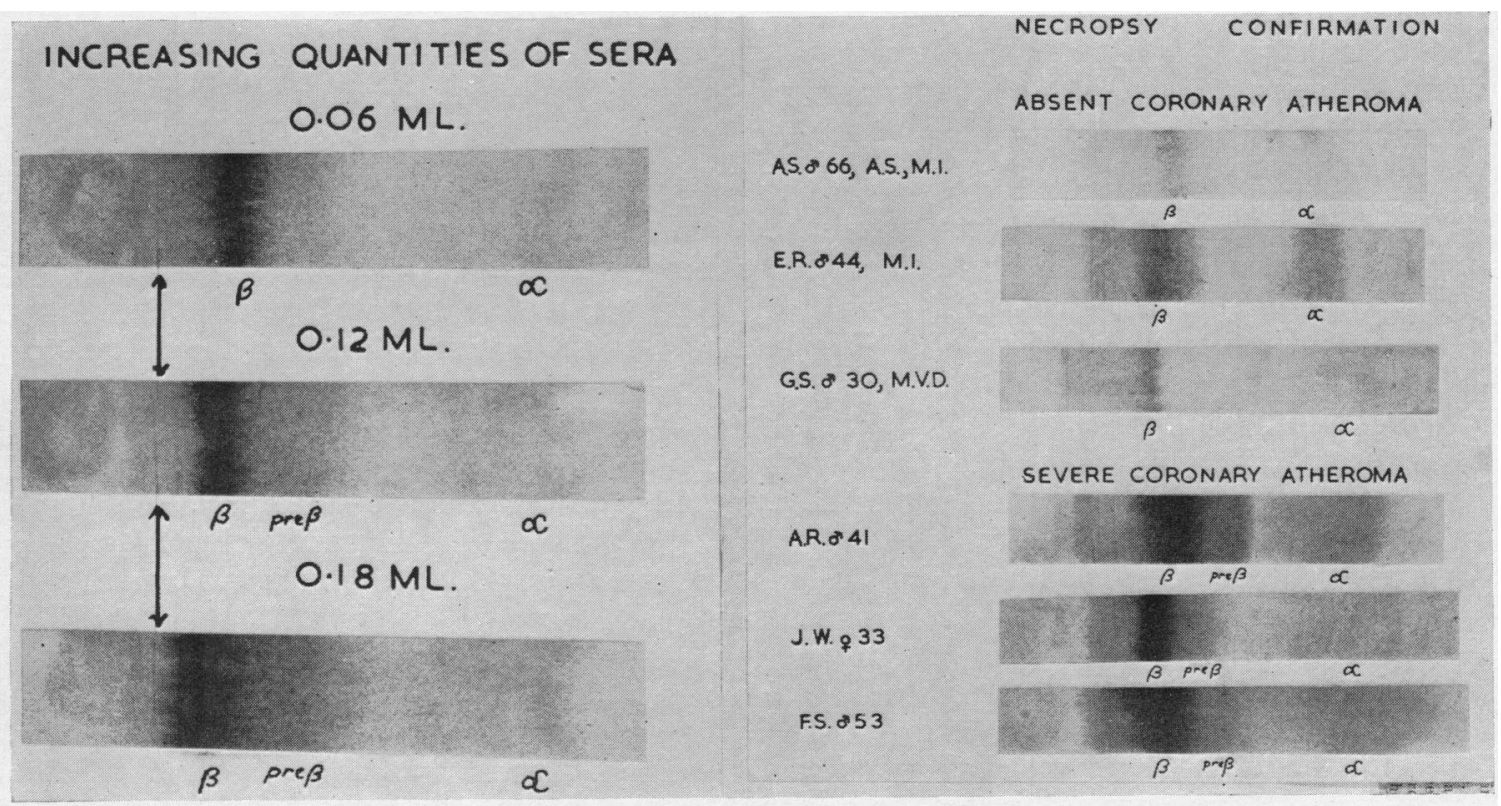

FIG. 9.-Lipoprotein pattern following electrophoresis of increasing quantities of sera. No demonstrable pre- $\beta$ lipoprotein when $0.06 \mathrm{ml}$. sera used.

FIG. 10.-Electrophoretograms of the lipoproteins from six patients subsequently examined at necropsy. 
Similarly, over zealous washing to obtain a white background after staining with Sudan black resulted in virtual disappearance of the band.

Thus it appears that the pre- $\beta$ lipoprotein is a distinct entity. It may be present in apparently normal subjects, but is found to a significant extent in 99 per cent of patients with cardiac ischæmia. Seventeen patients in the present series have been examined at necropsy. A significant pre- $\beta$ lipoprotein was present in each of ten cases with coronary atheroma, but in none of seven without coronary artery disease (Fig. 10).

Cholesterol. The serum cholesterol was estimated by the Myers and Wardell technique, and the results in ischæmic subjects have been compared with those in controls (Table III). Higher

TABLE III

Mean Serum Cholesterol Values

\begin{tabular}{l|c|c|c|c|c|c|c|c}
\hline & \multicolumn{3}{|c|}{ MEN } & \multicolumn{3}{|c}{ WOMEN } \\
\cline { 2 - 7 } & No. & $10-29$ & $30-49$ & $50-69$ & No. & $10-29$ & $30-49$ & $50-69$ \\
\hline Control patients & 47 & $\begin{array}{c}182 \pm 18 \cdot 5 \\
(14)\end{array}$ & $\begin{array}{c}197 \pm 10 \cdot 4 \\
(18)\end{array}$ & $\begin{array}{c}164 \pm 9 \cdot 3 \\
(15)\end{array}$ & 43 & $\begin{array}{c}148 \cdot \pm 11 \cdot 3 \\
(12)\end{array}$ & $\begin{array}{c}198 \pm 17 \cdot 9 \\
(19)\end{array}$ & $\begin{array}{c}206 \pm 17 \\
(12)\end{array}$ \\
\hline Ischæmic patients & 132 & - & $\begin{array}{c}160 \pm 12 \cdot 7 \\
(37)\end{array}$ & $\begin{array}{c}232 \pm 4 \cdot 8 \\
(95)\end{array}$ & 33 & - & $\begin{array}{c}237 \pm 20 \cdot 9 \\
(10)\end{array}$ & $\begin{array}{c}239 \pm 13 \cdot 3 \\
(23)\end{array}$ \\
\hline
\end{tabular}

mean levels were found in the sera of ischæmic patients, but the variation was considerable and the absolute serum cholesterol was of no diagnostic value in the individual. No relationship was detected between the serum cholesterol and the pre- $\beta$ lipoprotein. One control subject with a cholesterol of $330 \mathrm{mg}$. had no pre- $\beta$ band, whereas several ischæmic patients with a low cholesterol had plentiful pre- $\beta$ lipoproteins. Gross hypercholesterolæmia with xanthomata was associated with an obvious increase of the $\beta$ rather than of the pre- $\beta$ lipoprotein.

\section{THERAPEUTIC EFFECTS}

In addition to the lipoprotein pattern in ischæmic heart disease, the effects of various therapeutic agents on each of the three lipid fractions has been investigated. These effects were assessed by comparing the ratio of individual lipid to total lipoprotein before starting treatment, with the ratios found after varying periods of therapy in each patient. The significance of the difference, in either direction, was assessed by a $t$ test.

Fat Restriction. The value of fat restriction is still disputed, but some relationship between fat intake and atheroma undoubtedly exists (Katz, 1955). Twenty patients were treated for 6 to 18 months with a 1500-calorie diet containing $32 \mathrm{~g}$. fat $(12 \mathrm{~g}$. animal, $20 \mathrm{~g}$. vegetable fat). Many of these patients were treated initially with a more strict 1000 -calorie diet containing $24 \mathrm{~g}$. fat. Apart from this initially severe restriction during treatment in hospital, the therapy was carried out by the patients at home and could not be supervised.

No modification of the lipoprotein pattern was observed after three months' fat restriction, but after six months the pre- $\beta$ diminished, the $\alpha$ increased, and the $\beta$ lipoprotein was unchanged. The probabilities of observing these differences by chance were calculated: the values for $p$ were between 0.4 and 0.5 in respect of the pre- $\beta$, and between 0.1 and 0.2 for the $\alpha$ fraction. These results suggest a trend toward restoration to normal in the lipoprotein pattern, but the results are not statistically significant. A more strictly supervised short study or else a longer period of observation in these patients would be necessary before any certain biochemical benefit might be shown. The mean blood cholesterol of $270 \mathrm{mg}$. per $100 \mathrm{ml}$. showed no significant change after one year. No clinical improvement was found in this group of patients. 
Phenyl-ethyl-acetate. This substance was employed as a cholesterol-lowering medium by Cottet (1954). Its suggested method of action involved the blocking of coenzyme A in the liver, thus preventing the formation of active acetate and therefore reducing the synthesis of endogenous cholesterol from active acetate. No toxic reactions were reported.

Eight patients were treated with one gram t.i.d. of phenyl-ethyl-acetamide: toxic effects occurred in all. Generalized erythema occurred in one patient after three days of treatment. Drowsiness and dizziness caused us to stop therapy in a further five patients after three to four weeks and one of these five developed menorrhagia in addition. The drug was withdrawn in the seventh in view of increasingly severe angina, in addition to drowsiness. Recovery from these side effects occurred within four days of stopping treatment. Only one patient tolerated a long course of the drug; an initial four-week period of treatment produced no reaction, and after a month's interval therapy was started again and continued for ten weeks, when it was abandoned because of drowsiness and some erythematous patches.

Since four weeks' treatment was advised by Cottet to ensure a fall in cholesterol, the results in this small series are not strictly comparable with his. However, six courses of three to four weeks' treatment produced no significant change in serum cholesterol (mean 315 before and $350 \mathrm{mg} / 100$ ml. after). In the one ten-week course, the cholesterol levels were 320 before and $310 \mathrm{mg} / 100 \mathrm{ml}$. after therapy. Furthermore, weekly lipoprotein studies showed no significant changes in any of these patients when compared with control periods before and after the drug.

CEstrogens. In view of the greater susceptibility of men than women to ischæmic heart disease, œstrogens have been used extensively in experimental studies on atheroma and in the treatment of cardiac ischæmia (Katz, 1953; Oliver, 1954; and Rivin, 1954). High doses have been avoided in the present study, for it was felt that the discomfort of astrogen side effects was too great a burden to impose on patients already suffering from angina pectoris.

Initially a combination of ethinyl œstradiol and methyl testosterone was used in the hope that the feminizing effects of the estrogens might be antagonized by the androgen, leaving unhibited the effects on lipoproteins. Since this study was completed Russ (1955) has published evidence that androgens do in fact oppose this action of œstrogens. Our own experience with 13 patients supported this view. Six men and seven women were treated for three months with ethinyl œstradiol $0.06 \mathrm{mg} .-0.09 \mathrm{mg}$. and methyl testosterone mg. 30 daily. No significant change in lipoprotein pattern or in blood cholesterol was observed and this combined hormone therapy was abandoned.

Ethinyl œstradiol alone was then used in small daily doses of 0.05 to $1.0 \mathrm{mg}$. in 9 women and 18 men. Treatment was abandoned after three months in five of the women owing to menstrual disorders, but was continued in the remaining four. No patient complained of nausea, but mild gynæcomastia developed in five men after nine months' treatment, and was successfully countered by lowering the dose of œstrogen. Two men stopped treatment because they felt that the œstradiol aggravated their angina. No significant clinical improvement was observed in this series of 27 patients; four improved, five deteriorated (one of these died during treatment), and the remainder were symptomatically unchanged.

As only four women continued treatment for six months, no significance can be attached to these results. The results of estrogen therapy in the 18 men are shown in Table IV. Despite the low dosage of ethinyl œstradiol, a change in lipoprotein pattern was apparent after treatment for one month. No gradual trend was observed in the redistribution of the three lipid fractions in relation to the duration of therapy. However, the lower level of significance attained by the results after 12 and 15 months' treatment is largely due to the smaller number of subjects studied. The individual changes varied (Fig. 11): in some cases an increase of the $\alpha$ with a concomitant decrease of the $\beta$ fraction occurred, with little change in the pre $\beta$ fraction. This effect resulted in a distribution of the $\alpha$ and $\beta$ lipids comparable to that seen in normal women where the ratio of $\alpha$ to $\beta$ lipoprotein is higher than in men. In other cases a decrease of the pre- $\beta$ fraction was as marked as was this feminizing effect. If the pre- $\beta$ lipoprotein is in any way associated with atheroma, such a change indicated an improvement distinct from that of the solely feminizing redistribution $2 \mathrm{M}$ 
TABLE IV

Changes in Lipoprotein Fractions Observed in 18 Men with Ischemic Heart Disease during ESTROGEN THERAPY

\begin{tabular}{|c|c|c|c|c|c|c|c|}
\hline & & \multicolumn{6}{|c|}{ Mean of difference between start of therapy and } \\
\hline & & $\begin{array}{l}\text { After } \\
1 / 12\end{array}$ & $\begin{array}{c}\text { After } \\
3 / 12\end{array}$ & $\begin{array}{c}\text { After } \\
6 / 12\end{array}$ & $\begin{array}{l}\text { After } \\
9 / 12\end{array}$ & $\begin{array}{l}\text { After } \\
12 / 12\end{array}$ & $\begin{array}{l}\text { After } \\
15 / 12\end{array}$ \\
\hline$\frac{\beta}{\beta+\text { pre- } \beta+\alpha}$ & $p$ & $\begin{array}{l}\text { Minus } \\
0.049 \\
<0.02\end{array}$ & $\begin{array}{l}\text { Minus } \\
0.059 \\
<0.01\end{array}$ & $\begin{array}{l}\text { Minus } \\
0.062 \\
<0.02\end{array}$ & $\begin{array}{c}\text { Minus } \\
0.081 \\
<0.001\end{array}$ & $\begin{array}{l}\text { Minus } \\
0.036 \\
<0.4\end{array}$ & $\begin{array}{l}\text { Minus } \\
0.048 \\
<0.2\end{array}$ \\
\hline$\frac{\text { pre }-\beta}{\beta+\text { pre- } \beta+\alpha}$ & $p$ & $\begin{array}{l}\text { Minus } \\
0.038 \\
<0.01\end{array}$ & $\begin{array}{l}\text { Minus } \\
0.027 \\
<0.02\end{array}$ & $\begin{array}{l}\text { Miuus } \\
0.052 \\
<0.01\end{array}$ & $\begin{array}{l}\text { Minus } \\
0.051 \\
<0.01\end{array}$ & $\begin{array}{l}\text { Minus } \\
0.076 \\
<0.01\end{array}$ & $\begin{array}{l}\text { Minus } \\
0.064 \\
<0.01\end{array}$ \\
\hline$\frac{\alpha}{\beta+\text { pre }-\beta+\infty}$ & $p$ & $\begin{array}{c}\text { Plus } \\
0.087 \\
<0.001\end{array}$ & $\begin{array}{c}\text { Plus } \\
0.105 \\
<0.001\end{array}$ & $\begin{array}{c}\text { Plus } \\
0.112 \\
<0.001\end{array}$ & $\begin{array}{r}\text { Plus } \\
\mathbf{0 . 1 3 7} \\
<0.001\end{array}$ & $\begin{array}{r}\text { Plus } \\
0.104 \\
<0.01\end{array}$ & $\begin{array}{r}\text { Plus } \\
0.116 \\
<0.01\end{array}$ \\
\hline
\end{tabular}

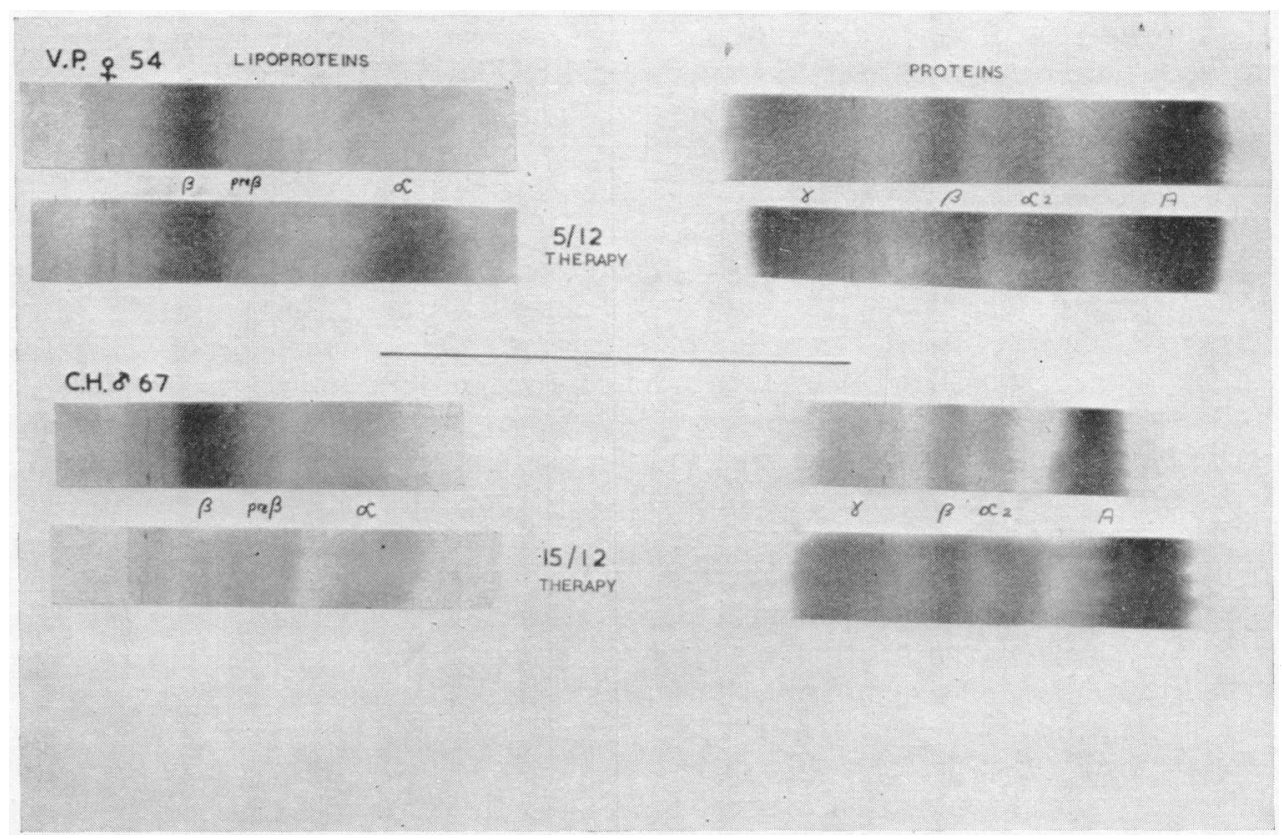

Fig. 11.-Electrophoretograms of lipoproteins and plasma proteins from sera of two patients receiving ethinyl œstradiol. After treatment, the serum of V.P. shows an increase of $\alpha$ and diminution of pre- $\beta$ lipoproteins. The serum of C.H. shows a large reduction in $\beta$ lipid, some increase of $\alpha$ and no change in pre- $\beta$ lipoprotein.

of $\alpha$ and $\beta$ lipid fractions. The overall results confirmed those of previous workers with regard to the rise of the $\alpha$ and diminution of the $\beta$ lipids (Robinson, 1955). In addition a decrease of the pre- $\beta$ lipoprotein occurred. Serum cholesterol values showed a rise from the mean pretreatment level of $228 \mathrm{mg} / 100 \mathrm{ml}$. Increases of 7, 11, and 19 per cent were found after treatment for three, six, and twelve months respectively. 
In order to determine the effects of massive doses of œstrogens I was supplied, by courtesy of the Institute of Urology, with sera from 21 patients who had received intensive œstrogen therapy for carcinoma of the prostate for 6-24 months: the clinical status of these patients was otherwise unknown to me. The lipoprotein fractions of these patients were compared with those found in men of the same age included in the preliminary study as control, atheromatous, and ischæmic groups (Table V). In the œstrogen treated patients the quantity of $\alpha$ approximated to that of the

TABLE V

Comparison of Lipoprotein Fractions in Various Groups

\begin{tabular}{|c|c|c|c|c|}
\hline & $\frac{\beta}{\beta+\text { pre- } \beta+\alpha}$ & $\frac{\text { pre }-\beta}{\beta+\text { pre }-\beta+\alpha}$ & $\frac{\alpha}{\beta+\text { pre }-\beta+\alpha}$ & Number \\
\hline $\begin{array}{l}\text { Controls * } \\
\text { Atheroma* } \\
\text { Ischæmia * } \\
\text { Estrogen therapy }\end{array}$ & $\begin{array}{l}0.511 \pm 0.021 \\
0.472 \pm 0.03 \\
0.491 \pm 0.013 \\
0.471 \pm 0.019\end{array}$ & $\begin{array}{l}0.093 \pm 0.014 \\
0.180 \pm 0.015 \\
0.218 \pm 0.005 \\
0.131 \pm 0.017\end{array}$ & $\begin{array}{l}0.396 \pm 0.027 \\
0.313 \pm 0.021 \\
0.277 \pm 0.0067 \\
0.415 \pm 0.021\end{array}$ & $\begin{array}{r}16 \\
19 \\
113 \\
21\end{array}$ \\
\hline
\end{tabular}

* These figures are taken from Table I for men aged 50-69 years.

$\beta$ lipid in contrast to the excess of $\beta$ in relation to $\alpha$ lipoprotein found in the other three groups. In the whole of this study, a similar approximation of $\alpha$ and $\beta$ fractions occurred only in the controls of both sexes under 30 years and in the women of $30-49$.

In these œstrogen treated patients with prostatic carcinoma the lipoprotein pattern included a pre- $\beta$ lipid in many cases. The mean value of this fraction was greater than that found in the control men of the same age, yet less than that of the atheromatous or ischæmic groups. The presence of this abnormal pre- $\beta$ fraction suggests that even massive œstrogen therapy cannot induce a complete reversion to normal of the lipoprotein pattern. Further conclusions cannot be made from these patients' sera in the absence of a full cardiological assessment and of lipoprotein studies before therapy.

Oral Heparin. The effects of systemic heparin on the lipoproteins have also been studied and will be published separately. Heparin therapy is not yet practical for long-term use outside hospital. However, Laborit (1954) and Scardigli (1955) claimed to have produced a heparin-like action on lipoproteins using a heparin-lipocaic tablet for sublingual administration. A similar sublingual tablet of heparin (without lipocaic) was prepared by Boots, containing 20,000 u. heparin. Seven patients received one to three tablets on 19 occasions; blood samples taken before, 1, 4, and 12 hours after treatment showed no change in lipoprotein pattern. Thus we were unable to confirm the sublingual absorption of heparin. The same patients had previously received $100 \mathrm{mg}$. heparin intravenously and the lipoprotein pattern was significantly altered in all. This change occurred within three minutes of injection and persisted for 12-18 hours.

\section{DisCUSSION}

This study has confirmed the existence of distinct pre- $\beta$ lipoprotein, first described by Dangerfield (1955). This lipid is insoluble in ethanol and its chemical composition is distinct from that of the adjacent $\beta$ lipoprotein and of the neutral fat " trail." A similar lipid appears to be present in electrophoretograms published by Rosenberg (1952), Ackmerman (1954), and Jencks (1956), but no previous authors have commented upon it. This oversight may be due to differences in staining techniques and quantities of serum employed. An $\alpha 2$ lipoprotein has been described by several authorities (Lewis and Page, 1952, 1953; Swahn, 1952; and Nikkila, 1953). The pre- $\beta$ lipoprotein, as its name indicates, is related to neither $\beta$ nor $\alpha 2$ globulin, but lies between the two. The $\alpha 2$ lipoprotein described by Kunkel (1956) may correspond to the pre- $\beta$ lipid. However we have not found a postprandial increase of the fraction as he observed. 
The present investigation suggests that this pre- $\beta$ lipid is found mainly in the serum of patients with atheroma. The association is not absolute as no pre- $\beta$ lipid was found in the sera of two of the 200 patients with ischæmic heart disease. Furthermore a well defined pre- $\beta$ lipoprotein was found in some young healthy men. The latter finding may be explained by postulating the presence of abnormal circulating lipids, even at a young age. Thus the presence of a pre- $\beta$ lipoprotein does not provide unequivocal proof of atheroma, but is highly suggestive. This association was further confirmed by comparison of the findings in 17 necropsies with the ante-mortem lipoprotein patterns.

Unfortunately it has proved impossible so far to arrange for ultra-centrifugal analyses of this lipoprotein. According to Page (1954), the $\beta 1$ and $\alpha 2$ lipoproteins correspond to the Sf 1-8 fraction-one that Gofman believes to be little altered in atherosclerosis. Kunkel (1956) has also shown that the $\mathrm{Sf}<12$ particles migrate as an $\alpha 2$ lipoprotein on electrophoresis, a fraction possibly corresponding to the pre- $\beta$ lipid. It has been suggested by Nikkila (1953) that the smallest lipid particles would be those most probably deposited in the intima. Therefore if a block occurred in the intimal fat metabolism or transport mechanism in atheroma, an increase of the smallest particles would be expected to occur in the serum. This theoretical concept gains some support from a necropsy controlled series of lipoprotein studies published by Paterson (1955). In those patients with atheroma Paterson found a significant increase in the Sf $0-12$ fraction alone.

The serum cholesterol level has little relation to the pre- $\beta$ lipoprotein; cases of hypercholesterolæmia had an increased $\beta$ lipid fraction. The serum cholesterol level in individual patients provided no significant index of atheroma, although the mean cholesterol value was higher in the ischæmic group than in the control group of subjects.

The pre- $\beta$ lipoprotein has also been investigated in several series of patients undergoing various therapeutic trials. In these serial studies this lipid has been altered by œstrogen alone, but has never been abolished. The persistence of the pre- $\beta$ lipoprotein is of particular interest in some patients in whom the $\alpha / \beta$ ratio reverted to normal. The fourth electrophoretogram (A.R.) in Fig. 10 was obtained from one of these patients: a significant pre- $\beta$ lipid was present. This 41 -yearold man subsequently died, during hormone therapy, and gross generalized coronary atheroma was found at necropsy. Similarly the pre- $\beta$ lipid was found in some patients receiving prolonged intensive œstrogen therapy for prostatic carcinoma. Therefore it is suggested that this lipoprotein may prove of value in the biochemical study of patients receiving various anti-atherogenic drugs.

In atheroma the $\alpha / \beta$ lipid ratio is reputedly altered by increase of $\beta$ and diminution of $\alpha$ lipoprotein. However, this change may have been exaggerated by inclusion of pre- $\beta$ lipid when measuring the $\beta$ fraction. From the present study the altered ratios would appear to be due chiefly to reduction of the $\alpha$ fraction and presence of excess pre- $\beta$ lipid, rather than to any significant increase of $\beta$ lipoprotein. Thus the pre- $\beta$ lipoprotein adds a further, and perhaps more specific indication of the presence of atheroma. No one biochemical technique can yet provide an unequivocal answer to the clinician's demand for information regarding the severity of atheroma in a patient. However, the simplicity of paper electrophoresis commends itself, notably in comparison with the technique of ultracentrifugation.

\section{SUMMARY}

The pre- $\beta$ lipoprotein has been shown to have a distinct chemical composition. A significant pre- $\beta$ lipid has been found in 99 per cent of 200 patients with ischæmic heart disease. This lipoprotein was also found in 42 patients with dominant aortic atheroma and occurred to a lesser extent in some of the 124 control subjects. Statistical comparison between the lipoprotein fractions in the sera of ischæmic and control subjects showed a consistently significant difference $(p<0.001)$ in the pre- $\beta$ lipid alone. It is suggested that the presence of a significant pre- $\beta$ lipoprotein provides a more specific indication of atheroma than does the $\alpha / \beta$ ratio.

The lipoprotein patterns were studied in different series of patients during treatment by fat 
restriction, phenyl-ethyl-acetate, methyl testosterone combined with ethinyl œstradiol, ethinyl œstradiol alone, and by sublingual heparin. Of these only ethinyl œstradiol therapy effected a significant redistribution of lipoprotein. No clinical improvement was observed in any of these series of patients.

I am most grateful to Dr. W. Dangerfield for instructing me in the technique of electrophoresis. Dr. Paul Wood has provided me with invaluable advice and encouragement and I am grateful to him and to the other physicians of the National Heart Hospital for their kind co-operation. I am indebted to Professor A. C. Frazer and to Dr. M. G. Sammons for undertaking the chemical analysis of the lipoproteins. Dr. P. Armitage of the M. R. C. Statistical Research Unit kindly assisted me in the statistical analysis. Beryl Hall provided invaluable technical assistance. The histograms were made presentable by Audrey Besterman.

Supplies of methyl testosterone, ethinyl œestradiol, and phenyl-ethyl-acetamide were supplied by British Drug Houses and the sublingual heparin by Boots' Pure Drug Co.

\section{REFERENCES}

Ackermann, P. G., Toro, G., and Kountz, W. B. (1954). J. lab. clin. Med., 44, 517.

Anitschkow, N. (1913). Centralbl. allg. Path. path. Anat., 24, 1.

Barr, D. P., Russ, E. M., and Eder, H. A. (1951). Amer. J. Med., 11, 480.

Cohn, E. J., and several others (1950). J. Amer. chem. Soc., 72, 465.

Cottet, J., Mathivat, A., and Redel, J. (1954). Presse. Méd., 62, 939.

Dangerfield, W. G., and Smith, E. B. (1955). J. Clin. Path., 8, 132.

Flynn, F. V., and de Mayo, P. (1951). Lancet, 2, 235.

Gofman, J. W., Jones, H. B., Lindgren, F. T., Lyon, T.P., Elliott, H. A., and Strisower, B. (1950). Circulation, 2, 161. Jencks, W. P., Hyatt, M. R., Jetton, M. R., Mattingley, T. W., and Durrum, E. L. (1956). J. clin. Invest., 35, 980.

Katz, L. N., and Stamler, J. (1953). Experimental Atherosclerosis. C. C. Thomas, Springfield, Ill., U.S.A. (1955). Ann. intern. Med., 43, 930.

Kunkel, H. G., and Trautman, R. (1956). J. clin. Invest., 35, 641.

Laborit, H., Delga, J., Baylon, H., Hugonot, R., and Dechen, J. (1954). Presse. Méd., 62, 79.

Latner, A. L., Molyneux, L., and Rose, J. D. (1954). J. lab. clin. Med., 43, 157.

Laurell, C. B., and Laurell, S. (1955). Lancet (letter), 2, 40.

Lewis, L. A., and Page, I. H. (1949). Fed. Proc., 8, 96.

-, Green, A. A., and Page, I. H. (1952). Amer. J. Phys., 171, 391.

- - (1953). Circulation, 7, 707.

Marchand, F. (1904). Uber Arteriosklerose (Athero-Sklerose), Verhandl. 21. Kong. inn. Med., $21,23$.

Nikkila, E. (1953). Scand. J. clin. lab. Invest., 5, suppl. 8.

Oliver, M. F., and Boyd, G. S. (1954). Brit. Heart J., 16, 124.

-,$\frac{1}{\text { I }}$ (1955). Brit. Heart J., 17, 299.

Page, I. H. (1954). Circulation, 10, 1 .

Paterson, J. C., Cornish, B. R., and Armstrong, E. C. (1956). Circulation, 13, 224.

Raynaud, R., and d'Eshouges, J. R. (1953). Bull. mem. Soc. Hôp. Paris, 69, 394.

Rivin, A. U., and Dimitroff, S. P. (1954). Circulation, 9, 533.

Robinson, R. W., Cohen, W. D., and Higano, N. (1955). Circulation, 12, 489.

Rosenberg, I. N. (1952). Proc. Soc. exper. Biol. Med., 80, 751.

Russ, E. M., Eder, H. A., and Barr, D. P. (1955). Amer. J. Med., 4, 19.

Scardigli, G., Salvini, L., and Aradas, A. (1955). Presse. Méd., 65, 1140.

Scarpa, A. (1804) in Willius, F. A., and Dry, T. J. A History of the Heart and Circulation. Philadelphia, 1948.

Swahn, B. S. (1952). Scand. J. clin. lab. Invest., 4, 98.

(1953). Scand. J. clin. lab. Invest., 5, suppl. 9.

Vogel, J. (1847). Pathological Anatomy of the Human Body. Trans. G. E. Day, Baillière, London. 